\title{
Forest birds of the right-bank forest-steppe of Ukraine
}

\author{
L. M. Moroz, E. D. Andriienko, S. O. Liulenko, S. L. Hrabovska, T. A. Nebykova
}

Pavlo Tychyna Uman State Pedagogical University, Ukraine.

E-mail: lulencoso@gmail.com

Received: 10.02.2020 Accepted 06.03.2020

\begin{abstract}
Forest biogeocenosis is a necessary environment for the normal existence of many species of wild animals, including birds. Recently, however, a gradual decrease in their numbers is observed in most forest areas of the Forest-Steppe zone.

This indicator is one of the most important criteria for estimation of the general condition of this or that ecosystem. In this regard, specialists-zoologists, ornithologists, etc. pay great attention to the study of this issue (Koval' N.F. 1982).

Currently, there is a quite extensive and often conflicting material regarding the number of birds. The most fundamental is the book by D. Lack, "The number of animals and its regulation in nature" (1957), which shows the influence of the food supply, the number of nesting places, "shelters", and enemies on the reproductive ability, survival and general dynamics of the number of many bird species. Determining the breeding intensity of specific species populations of bird, we proposed to use the so-called productivity coefficient, which allows us to compare both the degree of biomass stability over the breeding period during a number of years and its geographical differences. The total number of birds on nesting can be different in various parts of the range under the influence of environmental conditions. The number of birds nesting on the ground and in the underwood has recently decreased significantly due to the large recreational burden of forest cenoses. Consideration of the dynamics of the number of daytime predatory birds and owls is of special attention. Their numbers have recently stabilized, although it continues to decline in some regions according to the available literary data. Ornithologists consider this mainly as a consequence of environmental pollution, killing of birds by humans, destruction of their habitats. The number of animal populations, for example, can vary significantly during the year or on average over the years. It is determined by the breeding rate and mortality of individuals.

The breeding rate of birds is directly dependent on the size of egg laying, the success of eggs brooding and the percentage of flying out of viable young animals, which in total determines the success of breeding.
\end{abstract}

Key words: Forest-steppe zone of Ukraine; Ornithofauna; Biogeocenosis; Nesting

\section{Introduction}

The number of birds in a particular biogeocenosis is quite stable under certain conditions during the breeding season. It can change only with a radical change in environmental conditions. The total number of birds in broad-leaved forests of a certain region increases by 2.68 times on average under intensive breeding. The populations are represented by old and young individuals. The number of young couples can be very significant. The greatest species diversity of birds is noted, as a rule, in forests characterized by great floristic diversity. According to A.S. Malchevsky (1959), these include light broad-leaved forests with a predominance of oak, where at least $50 \%$ of the birds are cavity nesting birds, or mature broad-leaved and young forests at secondary serai stages. Great species diversity and bird numbers are observed near forest edges.

\section{Materials and Methods}

We observed regular nesting of 82 bird species with a total number of 613.88 individuals per $1 \mathrm{~km}^{2}$ and a biomass of $35.87 \mathrm{~kg} / \mathrm{km}^{2}$ during the nesting period in the forests under study. These data are similar to those of many authors who conducted research in mixed forests of the central part of Europe. Thus, 54 bird species with a total density of 404.3 couples or 808.6 individuals per 1 $\mathrm{km}^{2}$ annually nest in poorly changed forest landscapes of the northern part of the Forest-Steppe zone. There is evidence of nesting in this zone from 120-200 to 700-800 and even 1800 couples per $1 \mathrm{~km}^{2}$ of forest (Malchevsky, 1959). Fixation of the species composition and counting the number of birds was carried out mainly by the route method. The counts were carried out year-round with an interval of 15-20 days, and 3-5 days during the breeding period at about the same dates every month.

\section{Results}

A large number of bird species, as a rule, nest in those areas of forests that are less covered by human activity. This is also evidenced by the data of N.F. Koval (1981). Changes occurring in connection with the transformation of forest areas by a person lead to a violation of the natural ratios in the species composition of birds. Impoverished state of recreational forests by birds occurs mainly due to the species nesting in the underwood, undergrowth, and on the ground (Koval' N.F. 1981).

Researchers noted that males and females die in about the same amount. In most cases, young birds die: in the summer when they leave the nests and in the spring with a lack of feed.

The number of predatory birds has not changed significantly in the forests of the Forest-Steppe zone over the past 15-20 years. However, less commonly, large daytime predators nest sporadically - Milvus milvus, Clanga clanga, Bubo bubo. However, there has been a slight increase in the number of Buteo lagopus, Accipiter nisus, Falco tinnunculus, Falco vespertinus. The growth in the 
number of the last two species of birds is probably due to the widespread increase in the number of ravens in whose nests they inhabit.

There are various data regarding the dynamics of the number of predatory birds in the central European part. Some ornithologists note the currently observed stabilization. In particular, V.M. Galushin (1982) writes not only about the stabilization of the population density of most species of predatory birds in Europe, but also about its growth over the past 10-20 years. The number of rare bird species (Falco, Aquila, Haliaeetus, Gyps) continues to decrease. This is caused by a change in their habitats, the ruin of nests, etc.

V. M. Galushin divided all predatory birds in relation to human activities into three groups: those that are relatively tolerant, vulnerable and intermediate.

Much attention should be paid to social and economic problems in maintaining of a stable number of birds. In forest cenoses, it is necessary to limit hunting, which significantly changes the living conditions of birds. Thus, an important task was set for ornithologists - to develop methods for monitoring and controlling the processes of ornithocomplexes formation. It is necessary to minimize the effects of anthropogenic impact on birds. First of all, this concerns ornithocomplexes of forest lands both in densely populated and sparsely populated areas, which is the Forest-Steppe zone. It is known that the numbers of birds are variable. However, they characterize the average state of ornithofauna during a certain period of time and are considered by us from the point of view of evaluating one of the important characteristics of a balanced forest ecosystem. It is important to explain the reasons for the sustainability of forest biogeocenosis at the bioenergetic level. In our opinion, this approach has a certain scientific interest, since it will allow us to understand the principles and specific mechanisms of population autoregulation.

During the spring arrival period, the number of birds in the forests of the region increases significantly. A competition in birds is clearly observed, including for the best nesting territory due to the specific conditions of forest biogeocenoses in the early spring period, the lack of food, changes in weather conditions, the lack of reliable shelters, etc. Young birds are often ousted from their places of birth by old ones, as a result of which they are forced to migrate. In addition to the above, it should be noted that the old individuals often fly to last year's territories in already formed pairs, while young birds form them, as a rule, at the nesting site. Thus, a more intensive resettlement of young individuals, in comparison with the old ones, is a forced (random) process and is not fully combined with the well-known statement that they have insufficiently expressed territorial conservatism. The movement of animals does not go beyond the territory occupied by the population under a small number (Moroz. L.M. (2017) Grabovskaja S.L.). There is another, opposite opinion that the settlement (dispersion) of birds, in particular freely nesting forest species, in most cases occurs regardless of the density of their population and it should be understood as an inherent mobile stage of ontogenesis, and not just as hereditary properties of separate individuals. During the breeding season, the predominant majority of birds occupy certain, isolated stations and populations acquire a diffuse character. This is due to the need to provide the chicks with a sufficient amount of feed with the least energy. The chicks of different species of birds at a certain stage of a postembryonic development are fed with a certain type of food. Thus, the Paridae feed their chicks with small spiders, caterpillars in the first days after birth, and only after 7-10 days they provide them with the main food. The Sturnidae, in addition to the main feed, intensively provide the nestlings with small mollusks - the main source of calcium compounds needed for the nestlings to build the skeleton. Diffuse distribution of birds during breeding has other advantages for populations, since chicks of colonially nesting birds are more likely to be subject for spreading of various epizootics, ecto- and endoparasites, as a result of which a large number of them get sick and die. Cannibalism is often observed in open-nesting bird colonies (Koval' N.F., Zaplishnyj M.N. 1978).

We registered the regular nesting of 101 species of birds in forest biogeocenoses of the Right-Bank Forest-Steppe of Ukraine. The predominant number of species was noted during the route censuses; some of them (Clanga Clanga and Clanga pomarina, Aquila chrysaetos, Circaetus gallicus, Scolopax rusticola) were met in various forest stations. The number of these species is not given in the corresponding tables because of their great rarity.

75 species out of 101 ones belong to the forest group, the remaining 26 ones belong to the floodplain forest (Ardea cinerea, Pandion haliaetus, Haliaeetus albicilla, Remiz, Poecile), forest-steppe (Falco cherrug, Perdix perdix, Upupa epops, Lanius minor), polytopic (Falco tinnunculus, Passer montanus, Sturnus, Coloeus monedula, Corvus frugilegus, Corvus cornix), shrubbery (Lanius collurio, Sylvia nisoria, Sylvia borin, Sylvia communis, Sylvia curruca, Phylloscopus trochilus, Emberiza hortulana, Carpodacus) and forestry-edge groups according to their ecological belonging.

The composition of forest ornithocomplexes includes mainly migratory bird species (64), 27 are sedentary, 8 are sedentarynomadic, and 2 species are nomadic. This is the reason of the great differences in the species and quantitative structure of the summer and winter forest ornithofauna. Average data on the results of counting the number of nesting birds in forest biogeocinosis, the total length of the route is $166.68 \mathrm{~km}$, the accounting area is 746.6 ha (Table 1 ).

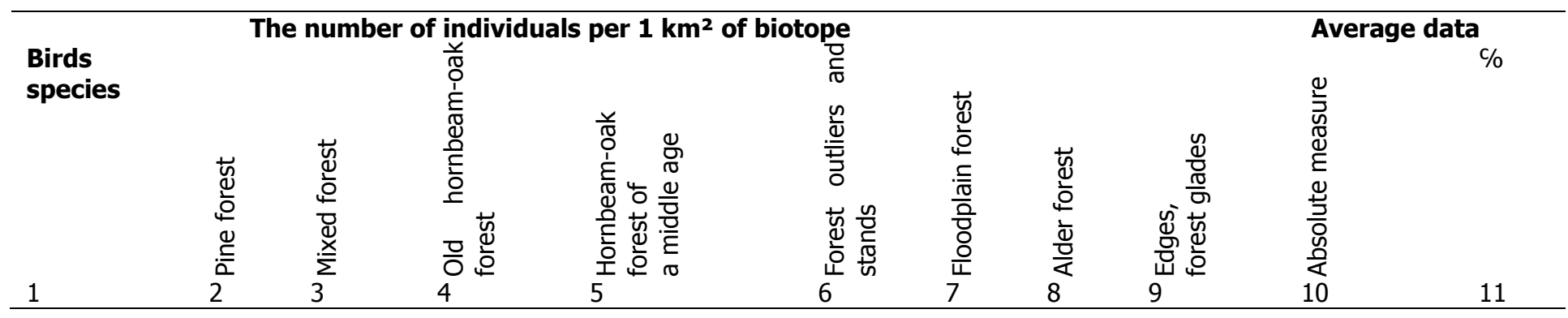

Table 1: The number of individuals.

The authors examined four pine forest areas. In this case, the age of the stand, the presence of a typical underwood of related species was taken into account. As already noted, pine forests in the conditions of the Forest-Steppe zone are not prevailing, although they sometimes occupy quite large areas. 45 bird species with an average number of 157.8 individuals per 1 km² were recorded on nesting sites in the area under research (212.5 ha). Buteo buteo was the most numerous among the daytime predators ( 2.03 individuals per $1 \mathrm{~km}^{2}$ ). Its number was five individuals per $1 \mathrm{~km}^{2}$ in the pine forest of a middle age (Pereiaslav-Khmelnytskyi district of Kyiv Region). Buteo buteo nests not only in young pine trees, although it can be found there quite often during the feeding. The number of other predator birds was small and ranged from 0.40 to 0.67 individuals per $1 \mathrm{~km}^{2}$ of biotope. 
Three species of Strigiformes nest in the forests of the Forest-Steppe zone: Bubo bubo, Strix aluco, and Asio otus. Strix aluco is the most common. Its average number is 1.34 individuals per $1 \mathrm{~km}^{2}$. It settles, as a rule, in old pine plantations. Thus, the colony density of Strix aluco reaches 8.42 individuals per $1 \mathrm{~km}^{2}$ in the old massif of Cherkasy coniferous forest.

Asio otus is also often found in old pine forests.

Dendrocopos major is the most numerous among Dendrocopos. In the old sections of the forest, its number is large enough, which is explained by the presence of trees suitable for cavities constructing and a good supply of food. In May 2017, 9.09 pairs of these birds per $1 \mathrm{~km}^{2}$ nestled in an old-age section of Cherkasy coniferous forest; the average number is 4.21 individuals per $1 \mathrm{~km}^{2}$ of biotope.

Phylloscopus sibilatrix is the most common among Passeridae - 8.15 individuals per $1 \mathrm{~km}^{2}$ of biotope/, Phylloscopus trochilus (5.45), Parus major (8.5), Fringilla coelebs (13.88), Passer montanus (10.78), Corvus frugilegus (8.71). Phylloscopus sibilatrix usually settle in a sparse forest which is rich for shrub underwood, Passer montanus settle closer to highways, glades, and Corvus frugilegus, as a rule, nest on the edges bordering with lowland meadows, river valleys and livestock farms.

Lullula arborea and Anthus trivialis, Turdus iliacus, Turdus viscivorus, Muscicapa striata, several species of Parus, Sitta europaea, Certhia, Carduelis chloris, Corvus corax nest in small numbers in a pine forest.

Analyzing the ornithofauna of the pine forest as a whole, it should be noted that it is the richest and most numerous in old (from 160 to 221.8 individuals per $1 \mathrm{~km}^{2}$ ) and middle-aged (207.5) plantations and relatively poor (48.6) in young plantings. We registered from 19 to 22 species of birds on nesting in the old forests, 14 - in the middle-aged forest, 8 - in the young forest.

The counting of the number of birds of the mixed forest was carried out in Kalynivka district of Vinnytsia region. The forest massif lies for a 6-7-kilometer zone, mainly along the right bank of the Southern Buh river. Hornbeam, oak, pine, spruce, birch are the forest-forming trees of the massif. Hazelnut, hawthorn, wartybark euonymus, elderberry, blackthorn, wild rose are among the shrubs. Wild apple trees, pears, and cherries are quite common in the forest stand. In general, the forest consists of middle-aged massifs, has sections of old and young plantings. The counting of species composition and the number of birds on a route with a length of $17.6 \mathrm{~km}$ which is a 50-meter zone with a total area of about 88 hectares was recorded. A partial analysis of the ornithofauna of similar biotopes indicates that the species composition of birds in the analyzed forest is typical for mixed forests of the region.

We registered 64 breeding species with a total number of 608.96 individuals per $1 \mathrm{~km}^{2}$ of the biotope. Parus major (40.91 individuals $/ \mathrm{km}^{2}$, or $\left.6.72 \%\right)$ is prevalent by the number, Poecile $(31.82$, or $5.22 \%)$, respectively, Phylloscopus collybita (27.27, or $4.48 \%)$, and Streptopelia (20\%, 45\%, or 3.36\%), Sylvia atricapilla (20.45, or 3.36\%), Phylloscopus sibilatrix, Luscinia, Fringilla coelebs, Passer montanus, Corvus frugilegus. Cuculidae, Jynx torquilla, Dendrocopos major, Lanius collurio, Erithacus rubecula, Turdus philomelos, Sylvia communis, Phylloscopus trochilus, Sitta europaea, Emberiza citrinella, Carduelis chloris, Oriolus oriolus, etc are common. The number of these species ranges from 9 to 20 individuals $/ \mathrm{km}^{2}$. Picus canus, Leiopicus medius and Picoides minor (from 4 to 6 individuals), Anthus trivialis, Turdus merula, Sylvia nisoria and Sylvia borin, Cyanistes caeruleus, Garrulus glandarius, Pica pica, Corvus corax nestle less. Their number, as a rule, does not exceed 5-7 individuals/km². Ciconia nigra is a rarely nesting bird. We did not find the nests of this bird, but we saw an individual searching for food in one of the forest glades. Apparently, Ciconia nigra nests in these places, since the "meeting" with it occurred during nesting time. It was confirmed by the residents of Kalynivka town, who repeatedly observed Ciconia nigra in the surrounding forests (Moroz L.M. 2017).

Accipiter gentilis and Buteo buteo are common among daytime predators -4.54 individuals $/ \mathrm{km}^{2}$. The nesting of Strix was noted in the same amount. Picus viridis is quite rare. In all likehood, the southeastern border of its range passes here, although individual pairs are sometimes found at nesting and somewhat south. One pair of Dendrocopos leucotos, Turdus iliacus, Turdus viscivorus, Sylvia curruca, Ficedula albicollis, Ficedula hypoleuca, Aegithalos caudatus, Lophophanes cristatus, Certhia, Coloeus monedula were found on the route. Also two pairs of Serinus - a typical representative of the forest zone were met. In the last period, the border of its range goes rapidly from the northwest to the southeast. In 2018-2019 we observed these birds in Sofiivka park (Uman city), which is $150 \mathrm{~km}$ south of Kalynivka town.

Nesting of Aquila chrysaetos was observed in 2018-2019 in one of the natural boundaries of the forest according to employees of Kalynivka Forestry. Recently, this predator has not been found here.

\section{Conclusion}

The number of animal populations, for example, can vary significantly during the year or on average over the years. It is determined by the breeding rate and mortality of individuals. The breeding rate of birds is directly dependent on the size of egg laying, the success of eggs brooding and the percentage of flying out of viable young animals, which in total determines the success of breeding.

\section{References}

Giljazov, A.S. (1981). Vlijanie letnih poholodanij na uspeshnost' razmnozhenija vorob'inyh Laplandskogo zapovednika [Influence of summer cooling on the success of breeding passerine Lapland Reserve]. Jekologija, 4 (in Russian)

Dol'nik, V.R. (1975). Migracionnoe sostojanie ptic [Migratory status of birds]. Moscow. Nauka (in Russian)

Dubinin, N.P., Toropanova, T.A. (1960). Nekotorye zakonomernosti rasprostranenija ptic lesnoj zony [Some regularities in the distribution of birds in the forest zone]. In Ornitologija. Moscow. Moscow State University (in Russian)

Il'ichev, V.D., Kartashev, N.N., Shilov, I.A. (1982). Obshhaja ornitologija. Uchebnik dlja studentov biologicheskih special'nostej universitetov General ornithology. [Textbook for students of biological specialties of universities] Moscow. Vysshaja shkola. (in Russian)

Il'ichev, V.D. (1982). Upravlenie povedeniem kak jekologicheskaja problema (na primere ptic) [Behavior management as an ecological problem (on the example of birds)]. Uspehi sovrem. biol. (in Russian)

Kashkarov, D.N. (1947). Osnovy jekologii zhivotnyh. [Fundamentals of animal ecology]. Leningrad. Uchpedgiz (in Russian)

Koval', N.F., Zaplishnyj, M.N. (1978). Uspeshnost' razmnozhenija ptic dubovo-grabovyh lesov juga Lesostepi Ukrainy [ Success of reproduction of oak and hornbeam forests in the south of the Forest-Steppe of Ukraine]. Kiev. Soveshhanija (in Russian)

Koval', N.F. (1981). Dinamika biologicheskih pokazatelej gnezdjashhihsja ptic ostrovnyh lesov juga lesostepi Ukrainy [Dynamics of biological indicators of nesting birds of island forests in the south of the forest-steppe of Ukraine] Zhurnal obshhej biologii, 4 (in Russian) 
Koval', N.F. (1982). Uspeshnost' razmnozhenija ptic ostrovnyh dubovo-grabovyh lesov Lesostepi Ukrainy. [Success of reproduction of birds of island oak and hornbeam forests Forest steppe of Ukraine]. In Jekologo-jetologicheskie issledovanija zhivotnyh. Voprosy biologii i ohrany prirody. Kishinev (in Russian)

Kuzjakin. A.P. O harakteristike rasprostranenija nazemnyh zhivotnyh. [On the characterization of the distribution of terrestrial animals]. Proceed. II Ecol. Sc. Conf. Kiev (in Russian)

Ljulenko, S. O. Goncharenko, G.E. (2009). Transformacija lisovih ekosistem Umanshhini. [Transformation of forest ecosystems of Uman]. Visnik Donec'kogo institutu social'noï osviti. Geografija, IV(4) (in Russian).

Moroz, L.M. (2017). Biologija i rasprostranenie lastochki beregovoj (Riparia riparia L) na primere s. Kunka Gajsinskogo rajona Vinnickoj oblasti [The biology and distribution of the swallow coast (Riparia riparia L) by the example with. Kuuka Gaysin district of the Vinnytsia region]. In environmental strategy for future: experience and news: Proceedings of the All-Ukrainian Scientific and Practical Conference (in Russian)

Moroz, L.M., Grabovskaja, S.L. (2017). Zhivotnye Umani s Krasnoj Knigi Ukrainy [Uman Animals from the Red Book of Ukraine] In Fauna of Ukraine at the turn of the XX-XXI centuries. New concepts of zoological research: Abstracts of Papers All-Ukrainian Zoological Conference. Kharkiv (in Russian)

Novikov, G.A. (1959) Jekologija zverej i ptic lesostepnyh dubrav [Ecology of animals and birds of forest-steppe oak forests]. Leningrad. Leningrad University Press. (in Russian).

\section{Citation:}

Moroz, L.M., Andriienko, E.D., Liulenko, S.O., Hrabovska, S.L., Nebykova, T.A. (2020). Forest birds of the right-bank forest-steppe of Ukraine. Ukrainian Journal of Ecology, 10(1), 237-240.

(cc) EY This work is licensed under a Creative Commons Attribution 4.0. License 